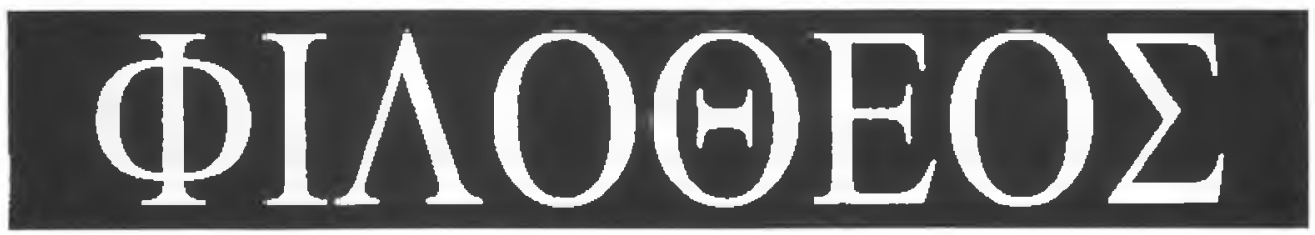

International Journal for Philosophy and Theology

Gunter Scholtz: Das Ende der Enzyklopädie - eine Tragödie der Kultur? ...................... 3

Wolfgang Speyer: Die Philosophie und die Wissenschaften: Möglichkeiten und Grenzen ...... 17

Jörg Splett: Anfang - Ursprung - Abgrund - Grund ............................................ 27

Vladan Tatalovic: The Son of Man Debate and its Relevance for Orthodox Theology ..... 35

Blagoje Pantelić: Logos became flesh - Theogony, Cosmogony, and Redemption (Sakharov versus Bulgakov).

Alois M. Haas: Apokalyptisches Hell-Dunkel...

Vladan Tatalović: Das Geheimnis der sieben Sterne und der sieben goldenen Leuchter

(Offb 1:20): die liturgische Funktion der Johannesoffenbarung ................................ 74

Anita Strezova: Apophaticism and Deification in the Alexandrian and Antiochene Tradition 83

Eirini Christinaki: The Undermined Contribution of Gregory the Theologian to Canon Law 102

Rodoljub Kubat: Der Jona-Kommentar des Theodor von Mopsuestia ........................... 117

Vasilije Vranic: The Cappadocian Theological Lexis in the Expositio rectae fidei of Theodoret of Cyrrhus

Evangelos Moutsopoulos: Des intellects divin et humain: adéquation ou inadéquation? Sur un commentaire de Denys l'Aréopagite.

Markus Enders: Grundzüge der philosophischen Apologetik des christlichen Glaubens bei Thomas von Aquin in seinen Schriften Summa contra Gentiles und De rationibus fidei.... 142

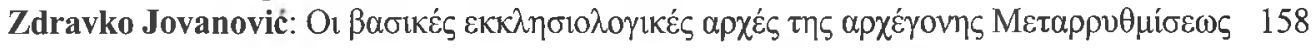

Walter Sparn: Luthers Intoleranz und das christliche Toleranzgebot ............................... 172

Friedo Ricken: Offenbarung und Vernunftreligion - Ihr Verhältnis nach Kants Religionsschrift 180

Vladan Perišić: Hegel's Triadology .................................................................. 186

Katharina Comoth: Über Anerkennung: Im Philosophicum gehts um die ,Gottesmaus ${ }^{6} 202$

Krzysztof Narecki: Dike in the fragments of Heraclitus of Ephesus .............................. 205

Zoran Devrnja: The Problem of the Identity of Covenant Community in Paul's Epistles to the Galatians and the Romans.....

Aleksandar Djakovac: Der Platz der Theologie in der christlichen Überlieferung der Orthodoxen Kirche......

Maksim Vasiljević: Time in Ecclesial Life............................................................... 237

Grigorije Durić: Constitutiveness of Otherness for Person and Church ........................... 248

Nichifor Tănase: Otherness and Apophaticism: Yannaras' Discourse of „Personhood” and the Divine Energy in the Apophatic Theognosia ....................................................... 254

Радое Й. Голович: Понять Россию сердцем: Кардиодикея и кардиогносия русского

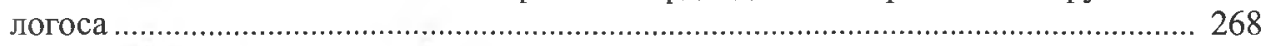

Zlatko Matić / Predrag Petrović: Holy Tradition in Theology of Yves Congar .............. 287

Bogoljub Šijaković: Identity between Memory and Oblivion, between Ontology and Discourse

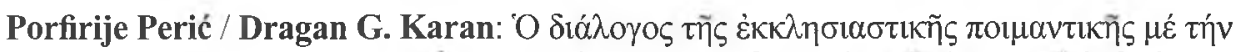

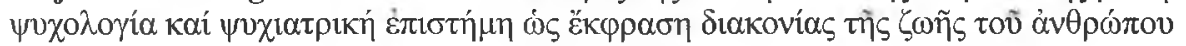

George Varvatsoulias: Do Nature and Nurture Influence Human Behaviour?

Todor Mitrović: Icon, Production, Perfection: Reconsidering the Influence of Collective Authorship Strategy on Contemporary Church Art ............................................. 337

Irinej Dobrijević: History and Dialectic Outreach: The Orthodox Churches in Oceania... 352

Book Reviews: Beierwaltes, Platonismus im Christentum; Beck, Dialogik - AnalogieTrinität (B. Sijakovic)

Authors in Philotheos 1 (2001) - 14 (2014) ............................................................ 374 
Nichifor Tănase

"Eftimie Murgu" University of Reșita, Romania

\section{Otherness and Apophaticism: Yannaras' Discourse of „Personhood” and the Divine Energy in the Apophatic Theognosia}

\section{Introduction: Absolutization and idealization of otherness}

At Yannaras and to Zizioulas there is an absolutization and idealization of otherness. which, together with freedom, are two fundamental attributes of personhood. Alterty acquires value and meaning only in relation with relational factors: love, fellowship and, also, being/nature. Due to the fact that, at Yannaras, nature denies apriori the persen as otherness (the ratio between person and nature is defined under the aspect of: prionty, inclusion, transcendence or conflict). S. Agouridic qualified both Zizioulas and Yamnaras as "fighter against/opponent of ousia" their ontology becoming personhoodologre It may be however dangerous to submit the person to a "dictated" or imposed otherness"

\footnotetext{
${ }^{1}$ Zizioulas confirms the essential importance of the concept of otherness and dedicates a whole chapu "On Being Other: Towards Ontology year of Otherness" in his work Communion \& Otherness: FurtheStudies in Personhood and the Church (London: T \& T Clark, 2007) 13-98, rom. trans. by Liviu Barbu Ioannis Zizioulas, Communion and Otherness. The personal-ecclesial Being, (Iași: Sophia, 2013). Ziziou las addresses the more post-modernist themes of identity and otherness, and he said that for Maximus. of erness is constitutive of the whole created universe, just as it is constitutive of the being of God as Tr: (Zizioulas, Communion and Otherness 26-27). The universe is ontologically grounded personally, thar = in a person, the person of Christ, the Logos. Otherness and communion coincide in Christ, and this axejunction triumphs over death. Also, the Palamite "essence/energies" distinction is another way of tryin $气$ a resolve this problem of the relationship between God and Creation (Zizioulas, Communion and Otherna 28-29; see also; Zizioulas, "The Doctrine of the Trinity: The Significance of the Cappadocian Contribe tion" Trinitarian Theology Today: Essays on Divine Being and Act, ed. Christoph Schwoebel (Edinburgt T\&T Clark, 1995) 44-60. But as Duncan Reid said: "In this regard he can to some degree accepr a criticisms of Palamite theology offered by Dorothea Wendebourg and, following her, Catherine LaCuz Zizioulas emphasises the difference between person and energy, a difference that he acknowledges become obscured in an over-emphasis on energy at the expense of person. While this is a generous conce sion to the critics of Palamism, I do not feel entirely persuaded by it. The Palamite distinction between $=$ and being should logically safeguard the notion of person, or for that matter of God, as more than at energy" [Duncan Reid, "Patristics and the Postmodern in the Theology of John Zizioulas" Pacifica 2 (2009) 308-316 at 314]. See also: D. Reid, Energies of the Spirit: Trinitarian Models in Eastern Orthe and Western Theology (Atlanta GA: Scholars Press, 1997); Catherine Mowry LaCugna, God for Us. Trinity and Christian Life (San Francisco: HarperSanFrancisco, 1991); Colin E. Gunton, The Promise Trinitarian Theology, 2nd ed. (Edinburgh: T\&T Clark, 1997).

${ }^{2}$ At both Zizioulas and Yannaras person identifies itself with grace [see: Nicholas Loudovikos . son instead of Grace and Dictated Otherness: John Zizioulas' final theological position," Heythrop Jown 52 (2011) 683-699, at 683]. This "dictated otherness" or imposed otherness by God to man is more the simple "asymmetrie", because it reduces man to a passive role, from which an important element is mis"is for partaking to His love, namely "the active human will" Otherness can only be mutual, namely dialogi= Otherwise we can not speak of communion, but of passivity" (Ibid, 693). N. Loudovikos argues that $z=$ oulas copies, as Yannaras, moreover, Levinas' heteronomy (asymmetrical relationship between the Onand the Ego that dominates), but it gives an essentially different meaning: "Zizioulas changes Levina
} 
which reduces or diminishes the size of the identity (the common nature of people). In a conception about intersubjectivity Other is more important than Ego and dominate it, and "the dialogically element and reciprocity, which are being inherent to the intersubjectivity and to the communion between people, are inevitably reduced". ${ }^{3}$ In reply to a "theology of the relationship" developed through ontology's speculations of the person was the assertion of both Lossky ${ }^{5}$, as well as Panagopoulos ${ }^{6}$ of meta-ontological and apophatic character of the person.

Yannaras reduces 'unity' to an absolutely singular, ontic 'oneness' by reducing the source of divinity to one, single hypostasis (i.e., the Father). In other words, 'communion' should reveal the existence of a 'perichoretic monarchy' (a perichoresis of love only) not a hierarchical, patro-centric one. Like Zizioulas, Yanaras' emphasis on a hierarchical model of monarchy (on the basis of the sole causation of the Father alone) is derived from his total identification of 'person' and 'one', wherein the nature of the monarchia is constituted by the communion of love between three persons, sacrificing, therein, 'distinction'

ethical priority in a complete ontological priority" (N. Loudovikos, A Eucharistic ontology: Maximus the Confessor's Eschatological ontology of Being as Dialogical Reciprocity, engl. trans. Theokritoff Elizabeth [Brookline: Holy Cross Orthodox Press, 2010] 10).

${ }^{3}$ Jean-Claude Larchet, Personne et nature. La Trinité - Le Christ - L'homme. Contributions aux dialogues interorthodoxes et interchrétiens contemporains (Paris : Cerf, 2011) 350-352 [Rom. trans. by Dragos Bahrim and Marinela Bojin: Jean-Claude Larchet, Persoanà si Naturâ. Sfânta Treime - Hristos - Omul (Bucharest: Basilica, 2013) 472-473]. Larchet shows that, while at Zizioulas the relationship seems to be a substitute for divine grace, at Yannaras there is a priority of relationship related to person: "Thus, paradoxically, it reaches to an absolutization of a relation and to a relativisation of the person" (p. 474). The French theologian accuses Yannaras of Nestorianism, starting from his statement that "in the person of Christ, human nature exists as personal hypostasis communion with the Deity" (Christos Yannaras, The Freedom of Morality [NewYork: St. Vladimir's Seminary Press, 1984], rom. trans. by Mihai Cantuniari: Christos Yannaras, Libertatea moralei [Bucharest: Anastasia, 2004] 48). Here it is activated the transcendent character of personal otherness, but human nature of Christ constitutes an hypostasis which doubles his divine hypostasis, which is a Nestorian idea (Yannaras, The Freedom of Morality 426).

${ }^{4}$ See: E. Russell, "Reconsidering Relational Anthropology: A Critical Assessment of John Zizioulas" Theological Anthropology," International Journal of Systematic Theology 5 (2003) 168-186.

5 "Apophaticaly understood, the origin relation points the difference, but not 'how' the divine birth and procession happen" (Vladimir Lossky, The Mystical Theology of the Eastern Church [New York: St. Vladimir's Seminary Press, 1976] rom. trans. by Vasile Răducâ: Vladimir Lossky, Teologia Mistică a Bisericii de Rấsârit [Bucharest: Bonifaciu, 1998] 51). See also: Aristotle Papanikolaou, "Divine Energies or Divine Personhood: Vladimir Lossky and John Zizioulas on conceiving the transcendent and immanent God"; Modern Theology 19.3 (2003) 357-385. Papanikolaou critically analyzes the implications of Zizioulas's theology which prioritizes hypostasis over energies for expressing the realism of divine-human communion (Lossky's Apophaticism and Zizioulas's eucharistic epistemology are reviewed in chapter 1: "Ontology and Theological Epistemology" of Aristotle Papanikolaou, Being With God. Trinity, Apophaticism, and Divine-Human Communion [University of Notre Dame Press, 2006] 9-48).

${ }^{6}$ Ioannis Panagopoulos, "Ontología è theologia toû prosópou. He symbolè tês paterikês Triadologías stén katanoés toû anthropínou prosópou," Sýnaxe 13 (1985) 63-79 and 14 (1985) 35-47. Panagopoulos questions the very possibility and legitimacy of developing an "ontology" of the person starting from the fourth century Greek patristic triadology. Fathers have adopted the term prosopon in order to avoid recognizing in hypostasis the absolute ontological content. The Greek Fathers were not really interested in "revolutionary" ontology by establishing an ultimate ontological principle in the Trinity, but in the simultaneous affirmation of unity and trinity of God. By emphasizing the apophatic distinction between divine being and trinitarian persons and accent focus on common energies, they excluded from the "being" any sense of an ontological necessity, and from the "person" any sense of an absolute otherness. Greek Fathers created a new "meta-ontology". Not triadology, but only Christology is one that can lead to a "theology" of the human person, because human nature is personal as divine-human. Not ontology, but theology reveals the truth of the person who is not an antropological category, but the event of divine-human existence of man, a mode of liturgical existence which man receives it through Baptism in the Church. 
for the sake of 'communion'. ' Colin E. Gunton argues that the priority of the Father in scripture is not ontological but economic, and expresses the Father's role in the trinitarian economy of salvation. If the priority of the Father were ontological, the particularity of the three persons would either be undermined or turned into an expression of subordination. Gunton avoids the language of 'being as communion' in favor of 'person with relational particularity.' He concedes that the relations of the three persons together are constitutive of their hypostatic particularity, yet he does not reduce the hypostases into these relations. He rather places the relations within their original epistemological framework: the trinitarian doctrine of revelation and here the incarnation is central. Showing that our understanding of personhood in terms of communion would be a limitation to personhood. Najeeb G. Award analyzes the triadological ontology of Gunton, for which "the revealed communion is a direct disclosure of the ontological particularity of the persons, not a total identification of the being of each person". ${ }^{8}$ In conclusion says Award: "The concept of 'personhood' that is based on a relational 'distinction-unity' model is, according to Gunton, what makes 'perichoresis' so needed by modern theology". ${ }^{9}$

For Yannaras, as Bishop Kallistos Ware has remarked, concern for the person, as the locus where being or nature is apprehended, constitutes the link binding patristic theology and existentialism together. ${ }^{10}$ Aidan Nichols would include among Palamite theologians masters such as Lossky, Florovsky, Evdokimov, Stăniloae, Yannaras, and Olivier Clement. ${ }^{11}$

\section{Yannaras's ecstatic otherness as perichoresis and kenosis}

Linguistic significants Father, Son and Spirit are perceived by Yanaras as "an element of revelation into the confession of Christ's disciples" "three selfconscious and logical Hypostases (personal) of the Causal Principle of the existing"12. The freedom of love relationship represents to Yannaras a "component of existential fact, it is one that "gives birth' to the hypostasis of personal self consciousness, the logical otherness". ${ }^{3}$ Thus.

\footnotetext{
${ }^{7}$ Miroslav Volf, After Our Likeness: The Church as the Image of the Trinity, Sacra Doctrina: Christian Theology for a Postmodern Age (Cambridge: W.B. Eerdmans Publishing Company, 1998) 78-79, 87. Apud. Najeeb G. Awad, "Personhood as Particularity: John Zizioulas, Colin Gunton, and the Trinitarian Theology of Personhood," Journal of Reformed Theology 4 (2010) 1-22, at 8-9.

${ }^{8}$ Colin E. Gunton, The Promise of Trinitarian Theology (Edinburgh: T\&T Clarke, 1993) 84-87; Gunton. "Trinity, Ontology and Anthropology: Towards a Renewal of the Doctrine of the Imago Dei," in Persons. Divine and Human: King's College Essays in Theological Anthropology, C. Gunton and C. Schwoebel (eds.I (Edinburgh: T\&T Clark, Ltd. 1999) 47-61, 56. Gunton, Being and Becoming: The Doctrine of God in Charles Hartshorne and Karl Barth (Oxford: Oxford University Press, 1978) 147; apud Najeeb G. Awad, "Personhood as Particularity" 16-18.

${ }^{9}$ It designates a lively, eternal movement of interpenetration as well as the "unity-in-variety of the divine economic involvement in the world" (Gunton, The One, The Three and the Mary 163).

${ }^{10} \mathrm{~K}$. T. Ware, 'Introduction', in C. Yannaras, The Freedom of Morality (New York: Et Crestwood, 1984) 10.

${ }^{11}$ Aidan Nichols, O.P., Light From the East. Authors and Themes in Orthodox Theology (London: Sheed \& Ward, 1999), Especially chap. XI: "Christos Yannaras and Theological Ethics" 183 and 213, n. 12.

${ }^{12}$ Christos Yannaras, Against Religion: The Alienation of the Ecclesial Event, romanian translation by $\mathrm{Tu}-$ dor Dinu (Bucuresti: Anastasia, 2011) 43-44. The Father's being is not represented as divinity, but is presented through fatherhood - non-predetermined freedom of existing - freedom which is also confirmed (fact becomes an existential) by generation of the Son and procession of the Spirit.

${ }^{13}$ Yannaras, Against Religion 47-48. God "wants to be Father: hypostatic freedom of self transcendence and self-sacrificing through love." The Being of the Son is represented by voluntary Filiation, namely selfdetermination as freedom of relationship with the Father. Spirit designates an "hypostatic otherness holding self-consciousness, which is not known, nor exist as ontic individuality but as existence send to Father's love."
} 
says the theologian and Greek philosopher, from the first moment of the apparence of the Church, the words Father, Son and Spirit mark a radical break between Christian metaphysics and ancient Greek ontology of the metaphysics that had into center the substance, the physiocratic religiosity. ${ }^{14}$

"What it is particular" to the person, his otherness, can not be determined, but only lived as fact, in other words as a relation. In this relationship of personal reference proves to be an opportunity for manifestation of person's otherness (of existential how or mode of existence) and, at the same time, it is defined relative to this otherness, it's manifest$e d$ as what it $i s$ only in the fact of relationship that reveals the otherness of the person. The relation discovers the person's otherness. The Ec-stasis is identified with the achievement of person's otherness. Eros is ecstasy's dynamic. Person's ec-stasis, the achieving of otherness, represents how man is "as universal." The personal otherness is the nature's mode of existence. ${ }^{15}$ Yannaras constantly asserts: "We all understand that what differentiates personal existence from every other form of existence is self-consciousness and otherness". ${ }^{16}$ The distinction between nature and energies is a prerequisite/premise of the possibility of knowledge of the unitary personal otherness. Only through natural energy or works is discovered, revealed, the way in which is the essence or nature, and this mode is the personal otherness.

The God of ecclesiastical experience is One and Triadic. For understanding the truth of the One God, the Church appropriates for its use the philosophical concept of one Essence (Ousia). For the definition of the three-fold state of God, it uses the concept of three Hypostases or Persons. So for the Church, God is consubstantial (one Essence- homoousios) and trihypostatic (three Hypostases or Persons). Nevertheless, says Yannaras "the distinction between Essence and Hypostases of Essence makes it easier for the Church to 'define' and describe the experience of the revelation of God". ${ }^{18}$

The monad, the Oneness of the Godhead "exists in trinity": "In theological language of the Christian East, says Yannaras, we call inclusion (interpenetration, gr. perichoresis) that mode of existence that transcends the ontic individuality of numbers without abolishing the hypostatic otherness of Persons". The hypostatic otherness is revealed in the "dynamic" reference and also in universal communion of each divine Persons with the other Persons of the Trinity, in a kind of self-hiding of each person in the relationship of communion with the other divine Persons, through the total absence of any element of existential independence, and this mode of communion's existence we call it inclusion/interpenetration. ${ }^{19}$ Without abolishing the unity of nature, personal oth-

\footnotetext{
14 Yannaras, Against Religion 49.

${ }^{15}$ Christos Yannaras, Person and Eros, romanian translation by Zenaida Luca (Bucuresti: Anastasia, 2000) $33,35,41$, and 43.

${ }^{16}$ Christos Yannaras, Elements of Faith: An Introduction to Orthodox Theology, (T\&T Clark: Edinburgh, 1991) 29, [romanian translation by Constantin Coman (Bucuresti: Editura Bizantină, 1996) 42]. The person "exists only as a self-conscious otherness" (Yannaras, Elements of Faith 30).

${ }^{17}$ Yannaras, Person and Eros, 81.

18 Yannaras, Elements of Faith, (T\&T Clark: Edinburgh, 1991) 26-27, (Bucuresti: Editura Bizantinā, 1996) 39. In Greek, the word for "essence" (ousia) means the fact of participating in being and is derived from the feminine participle of the verb "to be". But in the case of God, Yannaras says: "we cannot speak about participation in being, but about Being itself, the fulness of every possibility for existence and life. Therefore the apophatic formulation 'Being beyond all being'(s.n.) which the Fathers often use is closer to the expression of the truth of the God of the Church".

${ }^{19}$ Yannaras, Person and Eros, 264.
} 
erness is revealed into ec-stasis's reference of God outside of His nature, into the calling to communion and relationship which Personal God addresses it to personal man.

"We know" the personal presence of the Spirit as dynamic self-hiding, as work of revealing the person of the Logos..$^{20}$ Yannaras appoints the emptying as dynamic "selfhiding" of the Logos divinity in relation of communion with human nature. The meaning of asceticism is just attempting this kenosis, the "emptying" of individual independence elements, namely the person's successful achieving which is the fulfillment of hypostasis (gr. Hypostasis = "staying underneath, hiding myself as individuality in an universal ec-stasis of erotic communion")..21

The ontological conceptions of Eastern theologians from the beginning are based on the experience of personal relationship that becomes achievable only through the essence's works: the works (energies) differentiate and reveal personal otherness and at the same time they make known the property of the persons to be of the same being (the fact of having the same essence), since they are the common works of the common nature or essence. For Yannaras "nature exists only as the content of the person." 22 Bur we do not know God's person into the distance of individuality, but as empirical immediacy and personal relationship and communion through the Divine works. The beings as things are making known the logos of personal otherness that characterizes the divine creator work. We are approaching of the way of how it is the Godhead in itseli as a communion of persons, insofar as revealing themselves to us through divine work as anaphoric ec-stasis, calling at communion and relationship. ${ }^{23}$

The ecstatic reference of the divine nature through divine works constitutes a calling that gives to the being (ousia) which founds the personal opportunity "to be - in front of" the personal divine existence. God's calling comes into (gives) being in the human person. Distinguish/distinctiveness between divine nature and divine work, or nature-energies distinction is the "specific difference"24 between Eastern Orthodox theology and any other theological or philosophical ontology.

\section{Apophatic theognosia to Yannaras. The theological apophaticism \\ as iconicism also as affirmation of the absolute primacy of experience}

Christos Yannaras analyzes the nihilism-apophaticism binom, considering the nihilism as a theology of the absence and the apophaticism as a theology of lack of knowledgeIn nihilism, says Yannaras, not God is unreliable, but we are the ones who renounce to the ability to believe and seek God. Heidegger come to sustain that nihilism can have two possible consequences: "affirmation of God's absence or the recognition of lack of knowledge towards God. Heidegger thus come to recognize, in his own way, the theology's apophaticism of the neo-testamentary at least $t^{\prime 2} .{ }^{25}$

${ }^{20}$ Yannaras, Person and Eros, 266.

${ }^{21}$ Yannaras, Person and Eros, 268.

22 Yannaras, Person and Eros, 271.

${ }^{23}$ Yannaras, Person and Eros, 262.

${ }^{24}$ Yannaras, Person and Eros, 269.

${ }^{25}$ Christos Yannaras, On the Absence and Unknowability of God: Heidegger and the Areopagite, romanian translation by Nicolae Serban Tanaşoca, as Christos Yannaras, Heidegger şi Areopagitul, (Bucureşti: Anastasia, 2009) 47-48, 54. 
The West is also concerned with the apophaticism of Being, the inability of the human mind to exhaust through the definitions the truth of Being. In the West, the apophaticism results from the need to protect the mystery of the divine essence, in other words, it will be always the essence's apophaticism. ${ }^{26}$ Indeed, within the theoretical premises of the West, "any purely theocentric theory would risk to put the essence ahead persons, for becoming a mysticism of 'divine abyss' ( $v$. Gottheit of Meister Eckhart) an impersonal apophaticism of divinity-nothingness that precedes the Trinity". ${ }^{27}$

The apophaticism of scholastics, which leads to relativism, skepticism or even agnosticism, ignores the knowledge as direct empirical relationship. It is the apophaticism of the essence. Yannaras operates philosophical with the distinction between the essence's apophaticism represented by Western scholasticism, on the one hand and the apophaticism of person, characteristic of the East Greek Christian thought on the other. This distinction reflects for the Greek philosopher and theologian, not only a "mere methodological distinction, but rather an irreducible opposition both in gnoseology and ontology." 28 He characterizes his relational ontology as apophatic: "By apophaticism of the person I understand that I am starting from the belief that my existence and knowledge that I accomplish (the way in which I exist and the manner in which I know) are complex facts of relationship and the relationship is not limited to the intellectual determination but is fact of integral existence" ${ }^{29}$

Yannaras operates with the the circular triptych apophaticism-relation-energy based on the Aristotelian privative apophasis. Thus in the analysis of the Greek philosopher and theologian Aristotle distinguishes between the apophatic negation and privative apophasis (Metafizica, $\Gamma$ 1004a, 10-16), with this second sense, of privative apophasis, the apophaticism is used as theoretical knowledge way in the field of philosophy. In the Greek philosophical tradition, from Heraclitus to Gregory Palamas, characterizes it as apophaticism "refusing to exhaust the truth through its formulation, therefore the symbolical-iconological interpretation of the truth's formulations, adopting the dynamics of relations (of the heraclitic "communion") as a criterion of knowledge's confirmation" ${ }^{30}$

For Heidegger the initial interrogation from which philosophy starts is the one about the difference between beings and Being ${ }^{31}$ : We do not know the Being in Itself, we only know the way in which It beings what He is being, what it is. According to Yannaras, nihilism, as a refusal of identifying being with God, looks more "theological" rather than rationalist metaphysics. The two possible consequences of nihislism are the affirmation of God's absence or the recognition of God's non-recognition. ${ }^{32}$ In his way, Heidegger thus recognizes the apophatism of Theology, as Yannaras understands him. For the latter, the apophaticism represents the realization of an empirical relation-

\footnotetext{
${ }^{26}$ Yannaras, Person and Eros 37.

27 Yannaras, Person and Eros 38. Here Yannaras remembers the impasse which it creates the primacy of the apophaticism of Essence to Heidegger's texts (called by him the last "mystic of the essence" in the West).

28 Yannaras, On the Absence 10.

${ }^{29}$ Yannaras, On the Absence 21.

${ }^{30} \mathrm{Cf}$., On the Absence, 9; Elements of Faith, 27-28; Against Religion, 62.

31 Yannaras, On the Absence 51 (also cf:: Yannaras, Person and Eros 269)

32 Yannaras, On the Absence 53.
} 
ship with the designated reality. The relationship's cognitive fact saves the fundamental elements (Diversity and Freedom). Therefore, the apophaticism as active renunciation at the astonishment of knowledge in conceptual determinations, is the gnoseologic attitude that leads to dynamic of person's ontology. The Apophatism represents the destruction of idols made by intellect - destruction of God as being. Thus, God is "The one who does not being, as one who is above any essence". Thus, for Yannaras, the apophatic apheresis is progressive denial, meaning the renunciation of any rational category, of any ontic concept. ${ }^{33}$

The way in which God exists is manifested through His personal works, as " $a b-$ solutely diversity revealed in the ec-static relation, namely in Logos' work" ${ }^{34}$ For this reason, The Nothing from the apophatic theology is being represented precisely by God's works, namely by the ability of the divine personal existence to ec-sits, to sit-outside-itself. The ontological distinction between "essence" and "works", is being found by Yannaras in the Areopagite writings, distinction which he assimilates it in that "non-hiding as appearing" of Heidegger. God's work outside Himself represents the ability immanent to dynamics of divine personal existence..$^{35}$

Thus, the Palamite distinction between essence and work is founded on that unions and distinctions of Dionysius the Areopagite. Yannaras understands Areopagite distinctions in the sense of cognitive access at the "communion" or at the "divine essence-giring, life-giving works". And the "way of existence through communion we call it personal", he said. ${ }^{36}$

The relation's empirism is expressed through participation at divine Works. Thus divine works invite to an experience of participation, of sharing . The apophaticism leads to this union. The experience of personal relation, a relation of participation at the active manifestation of the other's diversity, this "cognitive dynamics of relation empirism is apophaticism". Yannaras says that "the apophaticism is the affirmation of the absolute primacy of experience as possibility and way of knowledge ${ }^{3} .{ }^{37}$ Here, as we can observea in the second part of the study, Fr. Stăniloae is talking even about an overcome of apophaticism of what is being experienced, the apophatism of what can not be experienced. ${ }^{38}$

\footnotetext{
${ }^{33}$ Yannaras, On the Absence 77-78.

${ }^{34}$ Yannaras, On the Absence 86.

${ }^{35}$ Yannaras, On the Absence 88, 90.

${ }^{36}$ Yannaras, On the Absence 91.

${ }^{37}$ Yannaras, On the Absence 94 and 96.

${ }^{38}$ To emphasize both mystical union with God and God's otherness, Stăniloae introduced the concept of two apophaticisme. Referring only to the apophatic knowledge, Stăniloae observed three levels: the apophaticisme of the positive and negative knowledge, the apophaticisme at the end of the pure prayer and the apophaticisme of the divine light vision. The revealed knowledge of divine energies is the work of the grace in viewing of the divine light. For Lossky the apophaticisme seems bound and co-extensive with theological personalism. The father Stãniloae's criticism to Lossky's approach is the overemphasis of the apophaticisme (there is no distinction between apophaticisme of the union and intellectual apophaticisme) in the detriment of the light vision. Apophatic-cataphatically method, the theosis, and the distinction between being and works of God, represents the guidelines of his epistemology. Lossky pointed out exclusively the apophatic knowledge and, consequently, increased the distance between theologia and oikonomia. Father Staniloae rejected both extremes: Lossky's metaontology and the ontological character of personhood claimed by Zizioulas Patristic model of Stâniloae is rather Palamite, focusing primarily on apophaticisme and on the relationship between person - energies. Dumitru Stăniloae start, long before Meyendorff, the neo-hesychast orthodox movement in twentieth century theology, being the most important representative from the contemporary Orthodox theologians who valued the Palamite hesychasm as an authentic orthodox thinking.
} 
The personal character of God resides also from the way of "mutual integration" (perichoresis) animated by love of divine Persons. Even after the Incarnation of Logos, teognosia remains apophatic, ${ }^{39}$ it keeps the character of real and personal relation. Theognosia's way identifyes itself, on the other hand at Yannaras, with the work of "salvation" of man "in Christ". ${ }^{40}$ The apophatic knowledge, as a fact of participation at the "Light" of fullness of Life, identifies itself with the attending to the body of the Church, which is the historic achievement of the way of existence of Christ, the way of the new human nature.

Ecclesiastical teognosia means uniformity of way of life: knowledge means deed and participation at a new mode of existence. Apophatic Teognosia becomes at Yannaras "erotical teonimie" ( theonaming), an ec-static existential dedication into the "teonim" unifying eros. ${ }^{41}$ The premise of erotic relation and communion is "a happy crying" and an "insane holiness" and premise of an apofatic-empirical theological knowledge. ${ }^{42}$

\section{Yannaras between Palamas and Heidegger: Palamas'distinction essence-energies - an existential interpretation of personhood and the identification of Hypostasis with energy}

The personhood's unity, like existential fact, involves the distinction between nature and energies/works, namely the possibility of "synthesizing of nature in personal ecstatic unity." 43

The acceptance or rejection of this distinction will determine either the abstract or the real character of theological knowledge, the attribution of theological truths to either rational certainty or existential experience. ${ }^{44}$

The person recapitulates the mode of existence of nature; we know the essence or nature only as the content of the person. The ecstasis of nature, however for Yannaras, it is the energy of nature: "only through the natural energy can one know the one who acts as personal otherness as well as nature and essence". ${ }^{45}$

God is known only as a personal revelation (and not as an idea of 'active' essence), only as a triune communion of persons, as an ecstatic self-offering of loving goodness. On the contrary, the rejection of the distinction between essence and energy means priority of the intellect as the way of knowledge, reducing truth to a coincidence of thought with the object of thought (adaequatio rei et intellectus). ${ }^{46}$

\footnotetext{
${ }^{39}$ Yannaras, On the Absence 106.

${ }^{40}$ Yannaras, On the Absence 108.

${ }^{41}$ Yannaras, On the Absence 110 and 119.

${ }^{42}$ Yannaras, Person and Eros 85.

${ }^{43}$ Yannaras, Person and Eros, 85.

${ }^{44}$ Christos Yannaras, "The Distinction Between Essence and Energies and its Importance for theology", St. Vladimir's Theological Quarterly 19 (1975) 232.

The antithesis between Greek philosophy and Christian experience is transformed by the Greek Fathers of the Church (sec. 2-14) in a "creative synthesis" that "without betraying the Christian truth and the apophatic knowledge" hold "the priority of participation through experience of the ecclesial's truth as against the intellectual, rational approach" (Yannaras, Elements of Faith, 30-31).

${ }^{45}$ Yannaras, "The Distinction Between Essence and Energies" 234-235.

${ }^{46}$ Yannaras, "The Distinction Between Essence and Energies" 239-240. God is accessible only as essence, i.e. only as an object of rational search, as the necessary 'first mover' who is 'unmoved', that is 'pure energy'.
} 
The marginalization of divine being, who is the source of energies, makes Zizioulas to actually ignore the divine energies ${ }^{47}$ in his Eucharistic and personalist ${ }^{48}$ theological vision. Subsequently he will directly oppose to the divine "energy concept". accusing the theology of St. Gregory Palamas of not being personalistic "The concepr of energy, not being itself, ontologically, a personalist concept, because it is cleari: different from hypostasis and common to the whole Trinity"49. Zizioulas says that there is the danger to maximize energies in the relationship between God and the world "the Divine energies as energies never expresse the personal presence of God, because they belong to nature and to all three Persons of the Trinity. If world and God should be united by the divine energies in their capacity as energies, the union should be a union with the three Persons, simultaneously, and not via Son - it should not be a $h y$ postatic union"s0. However, in St. Gregory Palamas' conception, there are three modes of union with God: after being (accessible to the persons of the Trinity), after hypostasis (the enhypostasized humanity in preexisting Person of Son) and after energy (the union of human person with God) ${ }^{51}$.

On the other hand, Yannaras gives a certain importance to the distinction between essence and energies, but he comes to bound energies to person: "Let's remember, Larchet says, that one of the gains of patristic theology was to clearly link the energies to

${ }^{47}$ Nonna Verna Harrison "Zizioulas on Communion and Otherness" St. Vladimir's Theological Quarterly 42 (1998): 273-300, here 278. As Harrison noted the divine nature by serves as "environment where [The Persons] are related to each other" (however, a better understanding is provided by the patristic word perichoresis, suggesting preservation of identity in overlap, better than the word "environment") in which "their bond is updated and they freely give themselves to one another." Thus, Harrison adds, Those Three. "are related to each other through the divine nature" (Ibid, p. 279-280). In a study refering of the theology of Yannaras [Nonna Verna Harrison, "Yannaras on Person and Nature," St. Vladimir's Theological Quarterly 33:3 (1989) 287-296], the Orthodox patrologian, noting the rejection of nature as a principle of divine unity. reproaches to Yannaras that unity of the Trinity is not only a relation between people, but a unity of nature and energy (Harrison, "Yannaras on Person and Nature" 288). See also Verna EF Harrison, "Gender, Generation. and Virginity in Cappadocian Theology," Journal of Theological Studies 47 (1996) 39-41.

${ }^{48}$ Zizioulas combines the two fundamental aspects of Cappadocian theology (the identification of hypostasis with 'person', and the monarchia of the Father) and moves the ontological weight in the Trinity from the concept of ousia to that of hypostasis. Therefore the being of God is identified with the person ( $c f$. Morwenna Ludlow, Gregory of Nyssa, Ancient and (Post)modern [Oxford: University Press 2007] see especially chapter 3: "The Social Doctrine of the Trinity - John Zizioulas and David Brown" 55). Zizioulas's strong advocacy of the priority of persons over substance in Cappadocian theology was criticized (Sarah Coakley Michel Rene Barnes, Lewis Ayres, David Brown, Lucian Turcescu, Aristotle Papanikolaou). Alan Torrance has attacked Zizioulas's 'personalist foundationalism' and 'personalist' ontology (Alan Torrance. Persons in Communion: An Essay on Trinitarian Description and Human Participation [T\&T.Clark, Edinburgh, 1996] 300, 289-90: "a foundational(ist) ontology of personhood together with attendant notions of personal freedom").

49 "On Being Other: Towards an Ontology of Otherness" in Communion \& Otherness 27.

50 "On Being Other: Towards an Ontology of Otherness" 29-30. See also: Aristotle Papanikolaou, "Divine Energies or Divine Personhood: Vladimir Lossky and John Zizioulas on Conceiving the Transcendent and Immanent God," Modern Theology 19:3 (2003) 357-85.

${ }^{51}$ Saint Gregory Palamas, The One Hundred and Fifty Chapters, A Critical Edition, Translation and Study by Robert E. Sinkewicz, C.S.B, Studies and Texts 83, (Toronto: Pontifical Institute of Mediaeval Studies, 1988) 171, Chap. 76: „There are three realities in God, namely, substance, energy and a Trinity of divine hypostases. Since it has been shown above that those deemed worthy of union with God so as to become one spirit with him (even as the great Paul has said, "He who clings to the Lord is one spirit with him" ( 1 Cor., 6.17) are not united to God in substance, and since all theologians bear witness in their statements to the fact that God is imparticipable in substance and the hypostatic union happens to be predicated of the Word and God-man alone, it follows that those deemed worthy of union with God are united to God in energy". 
nature, both in Trinitarian theology field as well as in Christology and that of anthropology, while many heresies tied it of person." "52

Yannaras sets out his ethics, as Maritain and Gilson, in the Western Catholic context, set out their metaphysics, by beginning from the disclosure of the divine name in Exodus 3 as 'I am He who Is'. In this divine word, the truth of existence, or the reality of being, is identified with God's personal hypostasis: " $\mathrm{I}$ "53.

Yannaras refers to a passage from the work of St. Gregory Palamas highlighted by Fr John Meyendorff, also in a personalist and existentialist perspective in which the divine person is "source et non produit de la nature" and in which Palama refuses to identify Being with essence: "Responding to Moses, God does not say, 'I am the being' but 'I am who I am'. Because the One who is/exists does not come from being, but the being is coming from The One who is. The one that is, This is the one who designed in Himself the whole being" ( $T r$. III, $2 \& 12) .^{54}$

Throughout the cited Palamite text, Yannaras sustains his idea of personal otherness of the divine love, an ontological category through which the personal hypostasis

52 Jean-Claude Larchet, Personne et nature 307-308 (rom. ed., 412-413): For St. Maximus the Confessor Christ has two works, because He has two natures: "I confess that any kind of energy is natural and not hypostatic" (Dispute entre Maxime et Theodore de Césaree en Bithynie, Corpus Christianorum Series Graeca 39 (Turnhout, 1977-) 107, 356-357). Cappadocian Fathers sustained against Eunomius the divinity of the Son and of the Holy Spirit in the sense that They have the same power and work (Basile de Césaree, Sur le SaintEsprit, Introduction, texte, traduction et notes par Benoît Pruche, O.P., deuxieme édition revue et augmentee, Sources Chretiennes 17bis [Paris: Editions du Cerf, 1968] 316-317). On the unity of nature and power to Gregory of Nyssa see: Michel R. Barnes, The Power of God. Dynamis in Gregory of Nyssa's Trinitarian Theology (Washington, D.C.: Catholic University of America Press, 1998). If Eunomius' theology indicates the substantial influence of a form of Neoplatonism (the "Neo-Aristotelians") upon his theology, Barnes said that "Gregory proposes his own alternative criteria for describing the relationship between Father and Son (and Spirit). He rejects Eunomius' description, which is based upon order and sequence, and instead he produces a description based upon connatural power or property. Gregory's argument is that because the divine

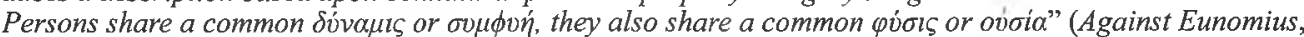
GNO 1:105:19-106), cf., Barnes, The Power of God 270-271, 276). Activity-based argument is use also for the Divinity of the Holy Spirit: "Gregory understands a formula like one nature because one power to be a suitable and credible statement of the unity among the Persons" (Barnes, The Power of God 306). Andrew Radde-Gallwitz holds Gregory of Nyssa as a precursor to the fourteenth-century distinction by Gregory Palamas of God's ousia and energeiai, the former of which, as simple, is entirely ineffable, whereas God is knowable through God's energeiai, which are not merely 'activities' but are God (Andrew Radde-Gallwitz, Basil of Caesarea, Gregory of Nyssa, and the Transformation of Divine Simplicity [Oxford: University Press 2009] 222-224). He find a number of scholars influenced by the twentieth-century neo-Palamite revival, who read Nyssen as a proto-Palamite are theologically sympathetic with Palamism (Archbishop Basil Krivocheine, "Simplicity of the Divine Nature and the Distinctions in God, According to St. Gregory of Nyssa," St. Vladimir's Theological Quarterly 21 (1977) 76-104). Radde-Gallwitz cited Christopher Stead, Verna Harrison, Robert Brightman and from a more recent example, David Bradshaw, who has published a survey of the use of the term energeia (David Bradshaw, Aristotle East and West: Metaphysics and the Division of Christendom [Cambridge: University Press, 2004)]. See also Barnes, "Dynamis and the Anti-Monistic Ontology of Nyssen's Contra Eunomium" in Arianism: Historical and Theological Reassessments, ed. Robert C. Gregg (Cambridge, Mass.: Philadephia Patristic Foundation, 1985) 330.

${ }^{53}$ Aidan Nichols, O.P., Light From the East. Authors and Themes in Orthodox Theology (London: Sheed \& Ward, 1999) 183, see especially chap. XI: "Christos Yannaras and Theological Ethics".

${ }^{54}$ Grégoire Palamas, Triades pour la défense des saints hésychastes, v. 2, Introduction, text critique, traduction, et notes John Meyendorff (Louvain: Spicilegium sacrum lovaniense, 1959) 383-767, at 665, apud John Meyendorff, Introduction a l'étude de Grégoire Palamas (Paris: Editions du Seuil, 1959) 291-293. The human nature and energies are "enhypostasized" in the person of the Logos because the latter is not an emanation or an internal radiation of divine essence, but the person of living God, possessing a unique existence and received the divine nature from Father's hypostasis. Thus Meyendorff says, "Le personnalisme theologique est le trait fondamental de la tradition à laquelle se refére Palamas: nous y trouvons la clef pour comprendre sa doctrine des énergies divines" (Introduction 292). 
of God recapitulates and exhausts the being "Neither Essence nor God's Energy do not constitute the Being, but personal mode of His existence: God as person is the Being"s hypostasis." 55

Beyond personalist interpretations, in its context, Larchet indeed shows that bein£

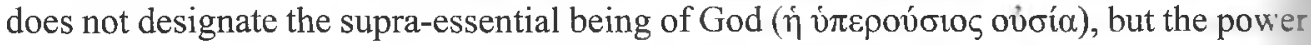

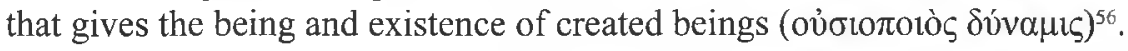

\section{Conclusions: Relationship of Palamite categories to the discourse of 'person' in contemporary Orthodox theology}

St. Maximus characterized the deification as an "enhypostatically enlighment", thus emphasizing its uncreated character because subsistence in / through the eternal hypostasis of the Word ${ }^{57}$ Also for St. Gregory Palamas God's work or energy is not hypostasis, bur in hypostasis, is not being, but in being, it's not self-subsistence, but subsistence in be-

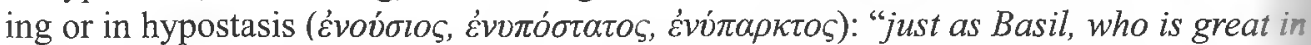
every way, says, 'The Holy Spirit is a sanctifying power which is substantial, real and enhypostatic.' Also in his treatises on the Holy Spirit he demonstrated that not all the energies derived from the Spirit are enhypostatic;206 and thereby he in turn clearly distinguished these from creatures, for there are reaüties derived from the Spirit which are enhypostatic, namely, creatures, because God made created substances". ${ }^{58}$ The work 15 called also "auto-hypostatic" because it doesn't irradiate from another hypostasis. The! don't compose the unity from which they come, because they don't exist like their ow hypostases, of themself, but into that particular hypostasis. St. Gregory shows that natural works do not come from a being contemplated outside hypostases, it rises from the being that real subsists only in the three hypostases. Nothing from what does exists it 15 never to be said that it is composed with its own work. Because those uncreated being many are simultaneously one and each of them enhypostatically (subsists in hypostasis I. and, in this sense, auto-hypostatic. And the natural works and hypostatic characters, be-

${ }^{55}$ Christos Yannaras, The Freedom of Morality 11-12: "Therefore, being is not related to the Essence which it would make of it an ontological necessity, but to The Person and to the freedom of love which founc it - which 'hypostasize' - in a personal Trinitarian communion". The Love that hypostasize God is not something common to the three Persons as the divine nature, but, at Yannaras, it is identified with the Father. See also, Christos Yannaras, Elements of Faith, (T\&T Clark: Edinburgh, 1991) 31, rom. ed. 44: "We have seen that from the beginning the experience of the patriarchs of Israel confirmed the personal character of Divinity: They meet him 'person to person', they speak with him 'face to face'. The God of Israel is the true God. that is, the really existing, living God, since he is the God of relationship, of personal immediacy. Whatever is beyond the possibility of a relationship, what is unrelated, is also nonexistent, even if human logic confirms its existence. On Mt. Horeb, Moses asks God himself to reveal his personal identity to his people by declaring his Name (Ex 3.13-14). 'I am the One who is', answers God, and Moses announces to the people that Yahweh (the 'I am') sends him and calls the Israelites to worship 'He who is'."

${ }^{56}$ Jean-Claude Larchet, Personne et nature 388.

${ }^{57}$ Questions to Thalassius 61, (PG 90, 644D-645D) in On the Cosmic Mystery of Jesus Christ, Selected Writings from St Maximus the Confessor, translated by Paul M. Blowers and Robert Louis Wilken (Crestwood, New York: St. Vladimir's Seminary Press, 2003) 131-143 [also in Phil. rom. vol. 3 (Bucharest: Humanitas, 2005) 304]: "He gives as a reward to those who obey Him the uncreated deification", and "the uncreated deification is calling 'the enhypostatically enlightenment' which has no creation"; "We suffer deity as beyond nature, but we don't produce it", because "no thing which is by nature does not produce deification" [cf. Thal. 22 cf. On the Cosmic Mystery of Jesus Christ 115-118; also in Phil. rom. vol. 3 (ed. cit.) 84].

${ }^{58}$ Palamas, The One Hundred and Fifty Chapters 122 (R. E. Sinkewicz ed.) 225. Basil the Great, saying that not all works are hypostasis, has shown that some works are created or they are themselves as creatures. 
ing many, converge into one, because none of them is in hypostas as self hypostatic, nor was before, nor shall be after, nor it is hardly possible to subsist in another essence as being part of its nature. ${ }^{59}$ From the distinction between hypostasis and uncreated hypostatic characters, Palama is going to distinguish between essential energies and essence, the first calling them enhypostatically ( $\dot{\varepsilon} v \pi \cos _{\sigma} \tau \tau \alpha$ ), and, by extension, the last with the

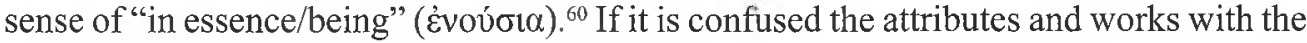
being, the being will be drawn from its incomprehensible mystery in a categorial order. Being exists only as real person, who is real and eternal mode of being's existence, also beings realy exist into the divine being as relation of trinitarian Persons with creation.

Empirical theology of St. Gregory Palamas is a mystical realism. And the problem of distinctions in the Holy Trinity is a soteriological problem and not a searching of the ontological definitions of divinity. To defend TABOR light, as the glory of the Son, this doctrine of the manifestation of the Spirit by energy, is related to the Christological dogma of the two natures in Christ. In conclusion, although starting from pneumatology, Palamas has Christology as an assumption of the distinction between essence and energies. ${ }^{61}$

One of the keys of today's continual misunderstandings of dogma and patristic theology, is that "some Orthodox begin to deal with St. Gregory Palamas in a non-patristic context"62, as Romanides shown in "Notes on the Palamite Controversy and Related Topics"63. The pseudomorphosis of scholastic / Augustinian Christianity "entered - Fr. Ică jr. says - even in modern Orthodox theology and 'neo-patristic' theologies, as the personalist existentialism (Meyendorff) or Eucharistic hypersacramentalism (Zizioulas), which replaces the spiritual deifying directly communion of man with uncreated energies or the personalistic Trinitarian analogy or idolatrous hypertrophy of the Eucharist which or confiscates the whole charismatic aspect of spiritual life, collectivised by force, or rejects it as an individual, monastic, non-Community platonic type therapy" ${ }^{4}$.

The patristic texts themselves dont found the reduceing of ontology to "personhood" (Yannaras and Zizioulas) or the use of a special charis-gracious "metaontology" (Lossky and Panagopoulos). We are therefore in the presence of a reduction of the essence or nature to/at the person or persons equivalence with grace. Ontology is either re-

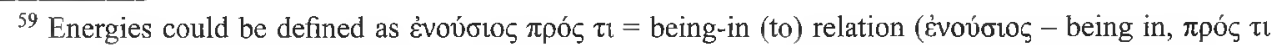
- relational intention), being with the sense of existential movement (Damascus) and to-be-in -view/vision (hypostatic intent of the communion in perichoretic love).

${ }^{60}$ The Church Fathers call those enhypostatically (Ėv $\pi$ ó $\left.\tau \alpha \tau \alpha\right)$, being in hypostasis, but not hypostasis

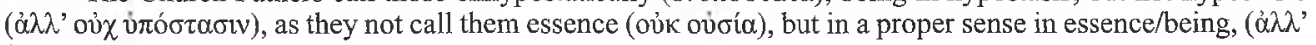
غ่voúota).

${ }^{61}$ Amphiloque Radovic, Le Mystère de la Sainte Trinité 295-296.

${ }^{62}$ For examples of the incorporation of Palamite insights into non-Palamite thought, see: George Maloney on G. M. Hopkins, Inscape: God at the heart of matter (New Jersey: Dimension Books 1978); Duncan Reid, "The Defeat of Trinitarian Theology: An Alternative View," Pacifica: Australasian Theological Studies 9 (1996) 289-300.

${ }^{63}$ The Greek Orthodox Theological Review 6: 2 (1960-1961) 186-205 (first part) and 9: 2 (1963-1964), pp. 225-270 (second part). Also published on the Internet (http://www.romanity.org). Romanides was referring to the fact that the scripturistical term from the Old and New Testament for @Éwoı is "worship" (glorification).

${ }^{64}$ John I. Icã jr., Canon of Orthodoxy. Vol I Apostolic Canon of the first centuries (Sibiu: Deisis / Stavropoleos, 2008) 51. In the center of "neo-patristic" Orthodox theology stands the reinterpretation of ecclesial experience in its many dimensions: mystical-palamite (Lossky, Stâniloae and Romanides), liturgical-eucharistic (Afanasiev, Schmemann and Zizioulas) historical-patristic (Florovsky and Meyendorff). 
duced to personhood disappears or is degraded by becoming mere physiology. Irreducible but inseparable the essence and hypostasis are requiering to each other: the essence is not hypostasis but is hypostatic, hypostasis is not the being but is existential-essential. Person is the space of plenary manifestation of being. Being- essence is not just a "given", but primarily a "gift" (donum), whose presence implies a giver (donans) - the person. So, true "personhood" does not contradicts, does not destroy but perfects and assumes "ontology". In a personalistic view, ontology is fundamentally donologie, exactly onto-donology. Distinguishing between essence-energy (that God exists), being-nature (which God is) and hypostasis-person (who and how God is), Cappadocian Fathers and St. Gregory Palamas made ontology (all these categories are ontological). Thereby, "the substance is known from the energy, not the energy from the substance" 65 - asserted Palamas. Father John I. Ică jr. adds: "Only by explanation of 'energetics', 'personalization' of Greek's substantialistes ontological (and anthropological) structures will be perfect, and the fundamental metaphysical scheme of the act-potency Aristotelianism will be creator and outdated modified, with a Palamite theological foundation". ${ }^{66}$

For Nicholas Bamford it is unclear yet the relationship of Palamite categories to the discourse of 'person' in contemporary Orthodox theology: "The juxtapositioning of personhood in neopatristic study to the philosophical, for example of the incorporation of the existentialism of Heidegger as evidenced by Zizioulas and Yannaras, has led to 'new' ways of looking at 'person' by re-addressing the Fathers through a synthesising of the relationality of Heidegger, Buber and Macmurray through existentialism. This in turn has led to the examination for the place of 'new ontologies', ${ }^{67}$ evidenced in the model offered by Zizioulas, and yet in this arena the re-engaging with Palamite theolog could help to balance the normative existentialisms of Zizioulas and Yannaras". ${ }^{6}$

Palamas does not indicate different types of energies but a unity of energy, of a type of energy that is yet multi-functional coming from/out, of the divine hypostases. the energies are common to the trihypostatic nature. Because the theias energeias is for Gregory Palamas enhypostatic, that is to say within and coming out from the hypostases of the Trinity, not from itself but made accessible through the oikonomia of the hypostases of the Trinity, energeia is not a thing in itself, it has no ontological centre. The reception of theias energeias brings a relational context to the 'person', entering into an ontological state or theosis, the possibility of a participation of the divine in the real.

Thus by studying the existential implications of Palamas in the modem debate considered by Yannaras, Meyendorff and Florovsky, Bamford arrive at the following conclusion: "in Palamas we see an opportunity to consider 'person' within a maximalist existentialism that is also ontological... by considering deification in the holistic sense, has implications in the category of 'person' on both an ontological level and on an existential level". ${ }^{69}$

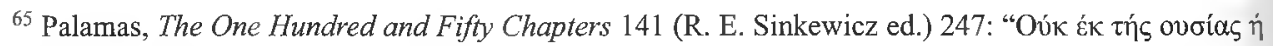

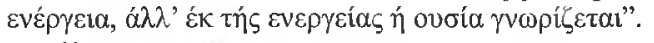

${ }^{66}$ Ioan I. Ică Jr., "Dialectics of St. John of Damascus-logical-philosophical dogmatic prolegomena" Studia Universitatis Babes-Bolyai 1-2 (1995) 125.

${ }^{67}$ See Paul Collins, Trinitarian Theology West and East: Karl Barth, the Cappadocian Fathers, and John Zizioulas, (Oxford: University Press, 2001).

${ }^{68}$ Nicholas Bamford, “Gregory Palamas' Energetic Approach to Person: Existential and Ontological Implications," Studia Patristica 48 (2010) 241-246 at 241-242.

${ }^{69}$ Bamford, "Gregory Palamas' Energetic Approach to Person" 246. 
The Latin opposition towards Greeks on the issue of knowledge and grace of God was already latent in the tradition of Augustinianism towards Cappadocian's traditions. To designate the two theological lines, André de Halleux" uses the terms of "scholastic" and "Palamism" (considered to be for the Western theology, the revealer of his relativity).

Unlike scholastic theology, Greek Fathers created a new "meta-ontology". In a personalistic view, ontology is fundamentally "givenness" exactly onto-givenness. Distinguishing between existence-energy (the fact that God exists), being-nature (what is God) and hypostasis-person (who and how God is) Cappadocian Fathers and St. Gregory Palamas have done ontology (these categories are ontological) ${ }^{71}$

${ }^{70}$ André de Halleux, "Palamisme et Scolastique. Exclusivisme dogmatique ou pluriformité théologique?," Revue Théologique de Louvain 4 (1973) 409-410. See also: Andre de Halleux, "Personnalisme ou essentialisme trinitaire chez les Pères cappadociens? Une mauvaise controverse," Revue théologique de Louvain 17 (1986) 129-155 and 265-292; André de Halleux, "'Hypostase' et 'personne' dans la formation du dogme trinitaire (375-381)," Revue d'histoire ecclésiastique 79 (1984) 313-369, 625-670; Christopher Stead, "Individual Personality in Origen and the Cappadocian Fathers," Arche' e telos: l'antropologia di Origene e di Gregorio di Nissa. Analisi storico-religiosa, ed. U. Bianchi and H. Crouzel (Milan: Vita e Pensiero, 1981) 182; Jean Pépin, "Yparxis et Hypostasis en Cappadoce," Hyparxis e Hypostasis nel Neoplatonismo: Atti del I Colloquio Internazionale del Centro di Ricerca sul Neoplatonismo (Universita' degli Studi di Catania, 1-3 ottobre 1992), ed. F. Romano and D. P. Taormina (Florence: Leo S. Olschki, 1994) 76; L. Turcescu, "Prosopon and Hypostasis in Basil of Caesarea's Against Eunomius and the Epistles," Vigiliae Christianae 51: 4 (1997) 384-385

${ }^{71}$ Christopher Stead, Divine substance (Oxford: University Press, 1977) 209-210, 214-215 and 218, discusses the idea of the substance of God in theological tradition having as central point the Nicaean homoousios. So he says, from Origen's Commentary on Hebrews, the word homoousios is associated with phrases describing the Son's derivation "from the substance" of the Father. Neo-Platonist writers roughly contemporary with Origen also used the term homoousios but only to suggests that the soul is akin to and consubstantial with divine things (Ennead, iv. 7.10). Porphyry also appears to have used the term homoousios to state the affinity of the human intellect with divine Mind (the second hypostasis of his trinity). However, Origen also used the term homoousios to indicate the Son's relationship to the Father; and he was the first greek writer to do so. It is therefore in Origen that we find the first suggestion of the trinitarian use of homoousios (being of the same nature with the Father). 